\title{
Expressions of Male-To-Male Intimacy in a UK Prison (and What We Might Learn From Them) Robert Blackash
}

\section{CONTEXT}

This paper is an autobiographical research piece exploring male-to-male intimacy in a UK prison setting during 2014. The research was undertaken as an act of "resistance" (Ward, 1997) to expose the reality of prison life and further the research agenda in relation to the rehabilitation of the criminalized. Ward (1997) suggests that all actions undertaken by those who experience abuse or marginalization by people in positions of power, might be seen as acts of resistance, and my research activity is both an act of resistance and also a positive assertion of my improved mental health, integrity, and selfregard. This paper is intended as one part in a series of pieces based on my research, all of which was undertaken at Her Majesty's Prison X.

Prison $\mathrm{X}$ is a part of the overcrowded UK prison estate relying on nineteenth-century accommodation designed for approximately 400 prisoners to incarcerate around 750 human beings. During 2014, a national re-organisation campaign saw the prison become primarily a location for sex-offenders and other vulnerable prisoners.

My first-hand experiences are my primary source of research evidence and many questions might be raised regarding this approach to "insider" research (Drake and Heath, 2008). This is my lived reality, for the most part recorded in the form of a handwritten prison diary. All names have been changed to protect the identities of the individuals concerned, and many of my subjects were fully aware of my academic interests because I followed the principles of "self-disclosure" as set out within Queer Theory (Semp, 2011). The prison authorities were given a number of opportunities to participate, which they consistently declined.

\section{ON QUEER THEORY AND A COUNTER-CULTURE OF MALE INTIMACIES}

Utilizing a dual theoretical approach, I access queer theory and those employing a similar methodology (Semp, 2011; Roseneil, 2007; Weems, 2007). I have also adopted an approach based on an interpretation of Foucauldian theory (Halperin, 1995; Sharpe, 2010; Danaher, Schirato \& Webb, 2000; Golder \& Fitzpatrick, 2009) on the intimacies that I experienced 
and witnessed in this "specialist" prison setting. At the time the research was undertaken, Prison $\mathrm{X}$ accommodated a mixed profile of prisoners including sex-offenders, prisoners identified as vulnerable if they had lived in a mainstream setting, and drug/gang affiliated prisoners separated from those in other institutions.

Moreover, queer theory is useful in non-traditional spaces, especially in the context of the prison (Berlant \&Warner, 1998). My research took place in an all-male prison, although transsexual prisoners were present (and my observations and interaction with one such individual, $\mathrm{K}$, are referred to here).

Prisons fit my interpretation of Berlant and Warner's (1998) definition of a counter-public space. In my interpretation, Prison X incarcerated prisoners, restricted public access and limited potential contact opportunities with the outside world. As such, 'normal' public appearance and performance were prohibited. As a consequence, rather than existing, traditional, British culture(s) being replicated by prisoners, a range of alternative, varied and nuanced relationships developed. The culture that exists within Prison $\mathrm{X}$ is not simply a sub-culture of wider British culture (Roseneil, 2007). Rather, the very excluded nature of 740 labelled "sex-offenders" (Foucault, 1977) and their physical isolation creates the necessary conditions for a "counter" cultural dynamic, which I seek to explore and define by examining a range of intimate relationships that existed between the men I observed, and considered as my peers, associates and, in some cases, my friends.

The dynamic to which I refer consists of, according to Roseneil (2007), a rejection of clichéd "heteronormative" relationships (Halperin, 1995) based on a romantic ideal of stereotypical familial settings, and instead is focused on complex, interwoven, uncertain, and ambiguous intimacies which abandon a simplistic dominant discourse (Foucault, 1977). The latter adopts a binary between "straight" and "gay" instead using a multiplicity of discursive strategies around intimacies - a deliberate pluralisation on my part - across a complex spectrum including heteroflexibility, prison-gay, and deep friendships.

As Kehler (2007) and Herek (2004) both write, within the hegemonic cultural context, a great many men are withheld from embracing (e.g. kissing in public) or expressing a fondness for each other. Herek (2004, p. 8) suggests that the stereotypical gender role for men means many never acknowledge their desire for the company of other close male friends or intimate male relationships. Whilst I would agree with Kehler's (2007) 
argument that the emphasis on masculinity has made male-to-male intimacy a "precarious business", within Prison X, expressions of intimacy were far more commonplace, and asserted a "dynamic" that exposed more varied and intimate "friendship practices" than anticipated.

I suggest that Bolsø (2012) offers some potential stages along the spectrum of intimacy that I adopt in my exploration of male-to-male intimacy in Prison X. Intimacy starts at the point where individuals care for each other. It develops as the care becomes physically expressed through touching - where that touching is more than might be considered the "norm" between two men in society. Moreover, it develops still further as that care, protection, and contact are accompanied by increased levels of "playfulness". I attempt to exemplify and expand on each of these stages throughout this paper. I also acknowledge that some intimate relationships develop beyond the level of playfulness through a series of further stages and lead to a range of sexual activities, but there is insufficient space to address these instances here.

I would not describe the intimacies I witnessed and participated in as simply second-best compensatory relationships (Roseneil, 2007), a poorman's alternative to "proper" heteronormative relationships "on-theoutside", because - as the following testament will evidence - these were not inferior or less significant relationships. In fact, some were far more important and I believe will prove life-changing because, at the very least, they demonstrated an attitudinal position on the part of many men, which differ from that anticipated in the hegemonic, heteronormative domain (Mac an Ghaill, 1994).

Almost 30 years ago, Davidson (1986) alluded to the levels of male intimacy in his work on Foucauldian archaeology, suggesting that intimacies existed beyond the "normative" roles referenced by Kehler (2007). However, I would like to start by presenting my evidence at the normative point, with reference to the simplistic labels of "straight" and "gay".

In a prison of approximately 740 prisoners, more than 80 of them attended a meeting for the GBT group (Gay, Bisexual and Transgender GBT was the preferred nomenclature of the group, although my personal preference would have been for the better-recognised LGBT). This meeting was held in September 2014 and was one of several I attended. At the "normative" level, the one associated with the dominant discourse of "gay" and "straight", over 10 percent of Prison X's population at that time were 
Journal of Prisoners on Prisons, Volume 24(1), 2015

confident in identifying themselves as GBT or GBT-friendly. Campaigning LGBT organisations such as Stonewall in the UK suggest that between six to eight percent of the adult population might identify as gay, whilst government departments, including the Department for Education, set a nominal target of securing 6 percent gay representation amongst their employees. So, despite the heteronormative climate that supposedly exists in prison settings, many men actively participated in a GBT focused event, more than might have been anticipated. As a result, I suggest we have the first evidence of "transgressive" behaviours (Madruieria, 2007), which are the focus of much research based in queer theory and counter-cultures.

Within this group situation, I witnessed elements of intimacy on the spectrum or continuum which Bolsø (2012) has led me to suggest exists, and which I explore here in three phases: 1) care; 2) care and contact; and 3) care and playfully-close contact.

\section{INTIMACY 1: CARE AND BOUNDARY TRANSGRESSIVES}

I had a close friendship with M, a long-term prisoner of a similar age (in his fourties), a divorcee and father. M identified as "straight". We were friends and physical contact between us was limited to a hand-shake, strong eyecontact, and a caring disposition. M shared intimacies relating to sexual relations he had with his ex-wife and accounts of his sexually-charged dreams in prison. He exemplifies, in this study and from my perspective, the modern gay-friendly straight man - open-minded and tolerant. Many other prisoners were similar in their interactions with me. I want to consider the extent to which these men were "boundary transgressives" (Madrueria, 2007). They were transgressive in so far as they recognised - perhaps subconsciously - that the shared location meant that some prisoners would develop different, 'less-conventional' relationships and styles of relating, as opposed to traditional, accepted bi-polar gay-straight intimacies. Furthermore, they were transgressive in their toleration of these alternative relationships and, thereby, failed to uphold a heteronormative hegemony (Roseneil, 2007).

However, $\mathrm{M}$ is also important because he shared a cell designed for single-occupancy with $\mathrm{K}$, a transsexual prisoner. There is insufficient space here to outline the infringement of K's human rights, the intrusion on K's feelings and the appalling impact on K's emotional state. However, the 
salient point in terms of this piece is that M, a straight man, demonstrated his emotional support for $\mathrm{K}$ by attending the GBT meeting, explaining to me that he wanted to be publicly seen as openly supportive of $\mathrm{K}$, and to be both discrete and sensitive enough that others in a similar position to K's and those wishing to talk with $\mathrm{K}$ could feel safe enough to approach their shared cell, even if $\mathrm{M}$ was in there alone. So, intimacy in terms of the care $\mathrm{M}$ showed towards $\mathrm{K}$ - and K's associates - did not simply transgress a boundary in terms of "enabling" as I suggest above, but also consisted of active transgressions on the part of $\mathrm{M}$.

This evidence suggests that the process of "abjection" described by Blackbeard and Lindegger (2007, p. 30) was weak. Those who I might have expected to maintain boundaries of normative behaviour, in this case boundaries associated with male intimacies, did not do so. Abjection was limited because those social actors who uphold certain heteronormative and hegemonic values were, perhaps, either too weak to do so - perhaps in terms of numbers or in terms of social status - or simply did not want to.

\section{INTIMACY 2: \\ CARE AND CONTACT - A FORM OF KINSHIP}

Whilst M's very public acceptance of K's transsexual status was an act of intimacy in terms of its work towards establishing a strong friendship, another form of intimacy existed that I interpreted as kinship (Berlant and Warner, 1998). The strategy commonplace in the vocabulary of ethnic minority prisoners was to use the slang term "fam" to describe a familial or brotherly level of intimacy that existed between them. In my second observed example, 24 year-old prisoner D became close friends with a significantly older gay-identifying prisoners, P. D, like many young white "street-wise" youth, adopted sub-cultural language and conventions from their ethnic minority peers, openly knuckle-touching, hugging, and referring to $\mathrm{P}$ as "fam".

The relationship, as I observed it, and as both $\mathrm{D}$ and $\mathrm{P}$ reported it to me, reflected a particular kind of older gay-man's "avuncular" idolisation of a handsome young person. Both maintained a level of intimacy and felt they benefitted emotionally from the relationship, while also attending the GBT meeting where $\mathrm{D}$ was the focus of some unwanted attention from several 
gay prisoners who evidently found him attractive - this had happened before - but this did not deter $\mathrm{D}$ from continuing to attend to be with $\mathrm{P}$. $\mathrm{D}$ and $\mathrm{P}$ had become friends more than 6 months prior in an educational setting, and, although physically located in separate parts of the prison and no longer in the same courses, they remained close friends, treating each other as "family", evidencing another level of intimacy that I disclose here within a Foucauldian-style analysis.

I witnessed a situation where $\mathrm{P}$ was reported to be the subject of some bullying by prisoner $\mathrm{F}$ - a 32-year-old straight prisoner. D and a close associated, $\mathrm{N}$ - also 24, a mixed-race father who identified as straight - collaborated and confronted prisoner $\mathrm{F}$ with a view of protecting $\mathrm{P}$ from further bullying, which was not homophobic in nature, although the motivation may have been. When we discussed their actions, D and $\mathrm{N}$ were adamant that they would not allow their "fam" (P) to be bullied by $\mathrm{F}$. Their identification was not then with another straight prisoner, but rather with a set of principles regarding "protection of family". Not only then was intimacy between male prisoners shown through deep tolerance, caring friendships, and active public demonstrations of the latter, intimacy also meant offering supportive intervention to secure and maintain familial relationships, despite the lack of biological "blood ties".

Two other points need to be raised at this stage in the paper. First, whilst $\mathrm{D}$ attended the GBT meeting, ostensibly to meet with $\mathrm{P}$, he was fearful of overt-gay attention in the session. His friend $\mathrm{N}$ would not attend the meeting despite being asked to do so. He admitted a fear of being "labelled" as gay. My point is that "boundary transgressive behaviour" was context specific and personal to the individuals involved. Second, the protective behaviours of $\mathrm{D}$ and $\mathrm{N}$ towards $\mathrm{P}$ crossed anticipated lines between sub-cultural groups on the basis of both age and sexual-orientation. This supports my assertion that a broader counter-culture existed within the prison setting, as opposed to a mere replication of sub-cultural groups on the outside.

\section{INTIMACY 3: CARE AND PLAYFULLY CLOSE CONTACT}

Bolsø (2012) also suggests that intimacy is reflected in playfulness. Above, I outline my assertion that this playfulness often accompanies elements of care and contact, and is the expression of a more significant 
level of intimacy. Prisoner $\mathrm{N}$ developed a more playful relationship with Prisoner Q, who is white, aged 45 and openly identified as gay. N, although straight, demonstrated his care for $\mathrm{Q}$ through the delivery of small gifts and services. Meanwhile, Q similarly cared for $\mathrm{N}$, assisting him in writing letters and reminding him of duties and obligations in the way a parent might remind a teenager. At this level, their public intimacy consisted of care, but was also manifested in touch - both hugged regularly and masculine "back-slapping" behaviour was commonplace between them. Here, the familial reference seen between D and P was less evident, although something similar might have been said to exist in the more public contexts of prison "association" (social times) and movement (when prisoners move between accommodation wings and vocational/educational facilities).

However, $\mathrm{N}$ and Q's relationship also featured a degree of playful, sexualised intimacy. Q pinched N's backside, and N was keen to show Q his muscular physique to the point that he sought $\mathrm{Q}$ out, inviting him to massage N's sore shoulders after over-exertion at the gym. N was fully aware that Q was gay, yet actively worked to develop and secure a relationship. N playfully sat on Q's lap in the private space of Q's cell and although neither reported anything overtly sexual happening, it was evident that the level of intimacy between them was more intense than that which I had witnessed between $\mathrm{P}$ and $\mathrm{D}$.

Weinberg (1972, p. 14), writing on the subject of intimacy between men, said "It is expected that men (even lifetime friends) will not sit as close together on a couch whilst talking earnestly... they will not look into each other's faces as steadily or as fondly (as women may)" (cited in Herek, 2004, p. 8).

However, I regularly observed $\mathrm{N}$ sitting close to $\mathrm{Q}$ in a physicallyrestrictive cell space and sustaining long-term physical contact whilst in conversation, even when a number of other prisoners were present. During the period of this research, Q left Prison X. Although I did not witness it, others reported that $\mathrm{N}$, a young straight male with a child and long-term female partner, wept. At this third level, the male-to-male intimacy, certainly from my experience, remained relatively open - it was neither covert nor secret, but was expressed through bonds of homosociality which were mutually stimulating, empowering and pleasurable for both parties. 


\section{CONCLUSION}

Roseneil (2007) suggested that "Queer Research" inevitably scavenges its approach from a range of psycho-sociological theories. In this case, I suggest that, across the spectrum of intimacy, we might find several of the fundamental human needs and "archetypes" which Jung (cited in Gilbert, 2010) identified. My research shows the powerful motivation on the part of prisoners to secure a sense of belonging and connection to others. In my experience, men who identified as straight attended GBT meetings for a range of reasons often associated with the different degrees of intimacy they experienced with their gay-identifying peers, friends, and fellow-prisoners. Similarly, prisoners who identified as gay also provided support, care, and affection in complex, nuanced and personal ways in return. Men from both 'so-called' gay-straight groups practiced homo-sociality and intimacy, which made the stereotypical traditional labels of "gay/straight" seem rather outmoded. As a counter-public space, the prison setting, rather than reinforcing stereotypical public definitions of sexual orientations, seemed to allow for more fluid performances based first on genuine friendship, care, and expressions of affection.

In this article, I have attempted to extract several small incidents from a significant body of research regarding male-to-male interactions and intimacy in a contemporary UK prison setting. The very nature of these prison settings as socially excluded locations makes them open to certain types of participant research and exploration of different behaviours, specifically the dynamics of homo-sociality. This led to a complex range of nuanced and context-specific responses, all underpinned by a psychological need, motivation, or desire on the part of men in prison to establish positive, supportive, and nurturing "relationships" with other men.

For research such as this to have value, it must impact social policy. More research is required, not only regarding the degrees of intimacy which might exist between men in counter-cultural "isolated" settings, but also into how intimacy might manifest differently in "Public Spaces", particularly given the legal changes occurring in several countries in relation to the Equality Agenda. In particular, future research might consider how far developing and dynamic societies interested in reducing incidence of crime and improving social relations might reflect upon the social status of individuals in regard to their sexual orientations. It appears that, if we are seeking to secure the 
rehabilitation of the criminalized and desistence from further conflicts with the law, we might do so by challenging hegemonic boundaries, questioning stereotypical labels of "straight" and "gay", and allowing for a more tolerant and accepting understanding of each individual and their motives to achieve that fundamental, core human need for intimacy and connectedness.

\section{REFERENCES}

Berlant, Lauren. and Michael Warner (1998) "Sex in Public", Critical Inquiry, 24(2): 547-566.

Blackbeard, David and Graham Lindegger (2007) “"Building a all around themselves': Exploring Adolescent Masculinity and Abjection with Photo-biographical Research", South African Journal of Psychology, 37(1): 24-46.

Bolsø, Agnes (2012) "Sociological Discipline and the Unruly Erotic", Review of European Studies, 4(1): 94-106

Danaher, G., T. Schirato and J. Webb (2000) Understanding Foucault, Los Angeles: Sage.

Davidson, A. (1986) "Archaeology, Genealogy and Ethics", in David Couzens Hoy (ed.), Foucault: A Critical Reader, Oxford: Blackwell, pp. 221-233.

Drake, Pat and Linda Heath (2008) "Insider Research in Schools and Universities: The Case of the Professional Doctorate", in P. Sikes and A. Potts (eds.), Researching Education From the Inside: Investigations From Within, London: Routledge, pp. 127-143.

Foucault, Michel (1977) Discipline and Punish: The Birth of the Prison, Alan Sheridan (trans.), New York: Vintage Books.

Gilbert, Paul (2010) Compassion Focused Therapy, London: Routledge.

Golder, Ben and Peter Fitzpatrick (2009) Foucault's Law, London: Routledge.

Halperin, David (1995) Saint Foucault: Towards a Gay Hagiography, Oxford: Oxford University Press.

Herek, Gregory (2000) "The Psychology of Sexual Prejudice", Current Directions in Psychological Science, 9(1): 19-22.

Kehler, Michael (2007) "Hallway Fears and High School Friendships: The Complications of Young Men (Re)negotiating Heterosexual Identities", Discourse Studies in the Cultural Politics of Education, 28(2): 259-277.

Mac an Ghaill, Mairtin (1994) The Making of Men: Masculinities, Sexualities and Schooling, Buckingham: Open University.

Madrueria, Ana Flavia do Amaral (2007) "The Psychological Basis of Homophobia: Cultural Construction of a Barrier", Integrative Psychological and Behavioral Science, 41(3-4): 225-247.

Roseneil, Sasha (2007) "Queer Individualization: The Transformation of Personal Life in the Early 21st Century", Nordic Journal of Women's Studies, 15(2-3): 84-89.

Semp, David (2011) "Questioning Heteronormativity: Using Queer Theory to Inform Research and Practice within Public Mental Health Services", Psychology and Sexuality, 2(1): 69-86. 
Sharpe, Andrew (2010) Foucault's Monsters and the Challenge of the Law, London: Routledge.

Wade, Alex (1997) "Small Acts of Living: Everyday Resistance to Violence and Other Forms of Oppression", Contemporary Family Therapy, 19(1). Available at www. solutions-centre.org/pdf/wade_1997.pdff.

Weems, Lisa (2007) "Un/Fixing the Fiend: Queering Pedagogy and Dangerous Desires", Educational Studies, 41(3): 194-211.

\section{ABOUT THE AUTHOR}

The author works as an independent researcher, exploring and writing about homophobia under his own name, though he also publishes as Robert Blackash (robblackash@gmail.com). He holds three Masters' Level Qualifications from Keele University and Oxford Brookes University in the UK. His research examines personal identities and the professional/social expectations of others. He is currently working on a $\mathrm{PhD}$ exploring attitudes towards gay-identifying people in the UK Public Sector. 